\title{
Impact of an Out-of-class Activity on Students' English Awareness, Vocabulary, and Autonomy
}

\author{
Siao-cing Guo \\ National Taipei College of Business, Taiwan
}

\begin{abstract}
Students in non-English speaking countries may be under the impression that they lack access to an authentic English environment. Outside the classroom, most students are immersed in a first-language environment with limited exposure to English. Out-of-class activities can be devised to show students that they are surrounded by English if they make a little effort to pay attention to the language as it is used in their daily lives. In this study, students were asked to observe and take notes on written English on display. In class, students discussed and analyzed the correctness and appropriateness of the English usage they had observed. A quantitative methodology was adopted to investigate the scale of students' language awareness before and after the activity. The results showed that this activity expanded students' awareness of the English language available to them outside the classroom and added to the degree of students' autonomy in learning.
\end{abstract}

The context in which learning takes place makes a vital contribution to the success of learning; this is true in particular for language acquisition. Countries in which English is not a primary language often lack an authentic English environment. In such countries, in-class instruction may be the only contact students have with English. Once students leave the classroom, they are totally immersed in their own first-language environment, which seems to offer little exposure to English materials and few chances to see or use English in real settings. Because sole reliance on classroom instruction is far from sufficient for EFL learners to practice the target language (Xiao \& Luo, 2009), more effort needs to be made to increase opportunities for these students to encounter English.

Recent reports indicate that for past three years, the English proficiency of students in Taiwan has continued to fall behind that of students in neighboring countries (Educational Testing Service, 2010; Hsieh \& Chu, 2006). To address that problem in an immediate way, this author suggests that teachers and students make better use of the authentic English resources that exist at the neighborhood level. These readily available resources could serve as an impetus for language growth. For that purpose, the author created the English Detective Activity. The challenge offered by the activity was to make students aware of the presence of English in their immediate environment and its usefulness in improving their mastery of that language.

Language Education in Asia, 2011, 2(2), 246-256. http://dx.doi.org/10.5746/LEiA/11/V2/I2/A07/Guo 
This paper describes the out-of-class activity, as it has been incorporated in a study intended to demonstrate its beneficial effects.

\section{Literature Review}

\section{Research on Out-of-Class Learning}

Most English classroom instruction and activities in Taiwan adopt textbooks or pre-selected materials. While these materials provide valuable information to learners, students seem to have little interest in them. Textbooks often fail to achieve a meaningful level of involvement on the part of the learners; learning need not be confined to the classroom with set textbooks and practice (Griffiths \& Keohane, 2000). Students need to develop the ability to acquire information that is available both inside and outside the classroom context (Field, 2007). Inschool learning tends to be symbol-based, while out-of-school learning is more directly connected to events and objects in the physical worlds, with the result that learning well in schools is not sufficient preparation for functioning well outside of school (Resnick, 1987). Hyland agrees: "[Language learning] can take place at any time and in any place, including the home and the community" (2004, p. 180). In a study by Nunan (1989), a majority of students found classroom instruction itself to be insufficient for the development of English competence; on the other hand, engagement in outside classroom learning enhanced their language development, demonstrating the need to incorporate activities outside the classroom for greater learning success.

Correlations are found between out-of-class experiences and educational gains among university students; these gains include complexity of cognition such as critical thinking and intellectual flexibility, growth in knowledge acquisition and application, humanitarianism, interpersonal and intrapersonal competence, and practical competence (Kuh, Douglas, Lund, \& Ramin-Gyurnek, 1994). Out-of-class activities can also foster language acquisition among EFL learners. Hyland (2004) noted significant out-of-class learning of English based on a study with 208 student teachers and 20 primary teachers in Hong Kong. Successful language learners were found to engage in various English activities outside the classroom. The immense benefits of out-of-class activities should lead institutions to use available resources to create opportunities inside and outside of school to accelerate students' learning.

\section{Benefits of Out-of-Class Projects}

Out-of-class project work addresses multiple needs and interests of students and creates a variety of authentic English language inputs (Bas, 2008; Hillyard, Reppen, \& Vasquez, 2007). Project Work (Fried-Booth, 2002) presents various project activities on different scales. Some can be carried out within one class period; some require weeks. The adoption of project work "[encourages] students to move out of the classroom and into the world" and "helps to bridge the gap between language study and language use" $(2002$, p. 7). Project-based learning allows teachers and students to move beyond the limitations of a traditional English curriculum (Foss, Carney, McDonald, \& Rooks, 2007). Engaging students in out-of-class projects offers the significant benefit of expanding the student learning environment. Realizing that their normal surroundings and activities offer meaningful opportunities to learn English is likely to spark interest and increase motivation to learn. Out-of-class activities are also linked with real life applications; this connection is key to fostering more authentic language usage and autonomy (Pearson, 2004). 


\section{Fostering Learner Autonomy}

Learner autonomy was first defined as "the ability to take charge of one's learning" (Holec, 1981, cited by Hui, 2010). According to Dam (1995), autonomous learners choose their own goals, time, materials, methods, and tasks, implement their choices, and then evaluate their actions. In an examination of the concept, Little (2007) revealed that the term derives from learner-centered theories within constructivist epistemologies; it is also referred to as "independent learning." He further specified (2009) that autonomous learners take the initiative in carrying out actions. As a result, they feel more competent in the things they do. Furthermore, this form of learning enhances learner maturity because it develops critical reflection, decision making, and independent action.

According to the above definitions, autonomous learning does not merely require conscious moves, but also metacognitive strategies such as planning, organizing, and reflecting on language learning. Some researchers speak of learning autonomy as a complex process that also involves affective and social factors such as learners' attitudes toward the target language and learning (Thanasoulas, 2000) and may even include a political aspect in that it allows students to take greater control of their lives and added freedom of choice (Reinders, 2010).

\section{Difficulties in Out-of-Class Activities}

Many college students in Taiwan demonstrate low motivation in school learning and are not likely to seek out learning on their own (Guo, 2011), but Little (2009) emphasized that if learners become more autonomous in language learning, their language use will escalate. If students are not motivated and do not take the initiative for self-learning, the teacher can facilitate the learning process by setting up a task with directions that will enable them to attain learning goals. In activity-based learning, the roles and responsibilities of the teacher and students are different from traditional instruction-based learning (Mathews-Aydinli, 2007). The teacher will act as a coach or a facilitator rather than an information deliverer, and students have to take a more active role when they cannot turn to immediate aid from the teacher. However, the teacher is not free of responsibility while students are engaged in out-of-class work. Instead, the teacher needs to provide students with assistance in acquiring the necessary materials and approaches to accomplish the task goal. This kind of learner-centered learning may be easier in theory than in practice.

EFL teachers often doubt the feasibility of out-of- class activities. Little (2009) attributed these concerns to three problems: (1) a lack of an adequate English environment, (2) a lack of knowhow for carrying out the task, and (3) the rigidity of the established curriculum, schedule, textbook, or exams. A shift of responsibility toward learners and an adoption of new classroom practices require changes in teachers' perspectives and commitment (Thanasoulas, 2000). The easily implemented out-of-class activity described in this study does not interfere with regular teaching. In the following sections, the author describes the design and implementation of the activity as well as its impact on students' language awareness through a quantitative methodology.

\section{Origin of Activity}

The idea for the English Detective Activity emerged as an expansion of the Passport Activity previously devised by the author. The Passport Activity encouraged students to visit sites both on and off campus where English was used. Some of the sites were preselected, and some were selected by the students. Students asked the site supervisors for a signature to confirm their findings. The activity was successful in significantly increasing students' awareness of English expressions used in locations around them. 


\section{English Detective Activity}

Following the Passport Activity, the author created the more intensive English Detective Activity, which requires students to collect examples and then evaluate language usage in reallife settings.

At the beginning of the semester, the author outlined the purpose of the activity to the students and provided guidelines. Students were to take on the role of English detectives, inspecting English usage in real-life contexts. They were required to go outside the classroom in search of objects and places where English words were used. They were informed that they would actually see English signs or words on the street or on products they used every day if they paid attention. To motivate them to participate, students were told they could choose the times and places they preferred and make the event a social excursion with friends so as to create an adventure in language. Students were instructed to take notes on the English expressions and the translations they observed. It was recommended that when possible they photograph the English text as evidence to use in their written report.

Guidelines for the English Detective Activity:

a) Students could work individually, in pairs, or in small groups. Pairs or groups would have to collect more language data.

b) Students could visit places on campus and other places of their choice to find English words and expressions. Students were to write down English words or phrases and / or their translation if the meaning or usage was ambiguous or incorrect. Students could also note interesting expressions for self-learning or to share with the class.

c) Students visiting businesses or agencies outside of school should explain the purpose of the activity to the staff there to prevent misunderstandings caused by the students copying down information or taking photos.

d) Each student needed to collect at least ten English words / phrases / expressions; however, the more, the better.

e) After collecting the language data, students were to examine the usage and analyze possible errors. Students could help each other with error analysis.

f) Students were to compile the language data and create an analysis report. The written report would then be emailed to the teacher by the given deadline.

In the study, students analyzed the English examples for errors in spelling, grammar (tense, word form), mechanics, and syntax. Prior to the activity, an analysis of sample data had been presented so that students understood what was expected of them. The students submitted a written report and the author compiled the student data to present in class. The whole class then discussed the correctness and appropriateness of the usage and translation of the examples. In terms of the presentation format, teachers who use this project can have students present the information either orally or in writing. The author has tried both approaches, which were equally effective.

Teachers can modify this kind of out-of-class activity based on the level of their students. Advanced students can be required to correct the problems they perceive. For lower-level students, it is advisable to limit the activity to collecting English vocabulary and usage because of the students' limitations in language analysis. Teachers can modify the activity to work on idioms, word collocations, syntax, or semantics. 


\section{Methodology}

The present study intended to investigate the effect of the out-of-class English Detective Activity on students' language awareness in an EFL learning environment. It incorporates students' voices, because students' feedback is perceived as an important source in determining how an activity or a program is to be run (Hsieh \& Chu, 2006). The study considered the following questions:

1. To what degree did students pay attention to English signs and usage outside of class in real life?

2. Did students' awareness of English used in their living environment outside of class increase after the English Detective Activity?

3. Did students' self-perceived language ability increase after the English Detective Activity?

\section{Instruments}

In-class surveys can serve as a base for instruction decisions and provide feedback to teachers for improvement (Davies, 2006). In order to investigate the degree of students' language awareness before and after the English Detective Activity, a twelve-item questionnaire was administered both before and after the activity. Seven questions probed the degree to which students paid attention to English used in real-life settings, and five questions examined students' attitudes toward language awareness and instruction, including practical usages.

\section{Participants and Procedures}

A total of ninety English major students in fourth-year study at a five-year junior college in northern Taiwan participated in this study in 2010. The students were the equivalent of freshmen at a general university. The five-year junior college system offers studies with a practical focus on professional skills. To enter this system, students must graduate from junior high school and pass a national entrance exam (Ministry of Education, 2010).

At the beginning of the semester, the author assigned the English Detective Activity and administered the pre-activity questionnaire. Students then had about three months to complete the project by visiting places on and off campus to gather vocabulary, interesting expressions, and translations in real settings. Three months later, the post-activity questionnaire was given, with 88 returned. The final notes on language data were also collected.

The questionnaire was checked by two English teachers for face validity. The Cronbach's alpha coefficient was 0.89 , which showed that the items on the questionnaire had a high internal reliability consistency. A paired samples t-test was computed to determine the statistical significance before and after the experiment.

\section{Results and Discussion}

\section{Students' Attention to English Signs and Usage Outside of Class}

The study results showed that prior to the activity, students paid very little attention to the English used in their daily lives. When asked about the English signs and usage on campus, the majority, $53.3 \%$ of students, rarely or never paid attention to them, $34.4 \%$ sometimes did, and only $12.2 \%$ often did. As for English on products they used daily, $45.6 \%$ rarely or never paid attention and $40 \%$ sometimes did, while only $14.4 \%$ did so often or very often. With restaurant menus, however, the percentages were reversed; $35.5 \%$ of students paid attention to the English usage on menus, $44.4 \%$ sometimes, and only $20 \%$ rarely or never. 


\section{Students' Awareness of English in Their Living Environment After the Activity}

After the activity, the level of students' attention changed dramatically in regard to awareness of English usage on campus, on daily products that they used, on street signs, on store merchandise, and on restaurant menus. The survey results before and after the experiment showed a statistical significance (.000) in the above-mentioned areas (see Table 1). Regarding students' attention to the translations of English expressions used in real settings, the results still illustrated a significant difference (.010) prior to and following the activity.

Table 1

Results of the Paired Sample t-test on Students' Language Awareness Pre- and Post-Activity

\begin{tabular}{|l|c|c|c|c|c|}
\hline & $\begin{array}{c}\text { Means } \\
\text { Pre-test }\end{array}$ & $\begin{array}{c}\text { Means } \\
\text { Post-test }\end{array}$ & Std. Dev. & $T$ & $\begin{array}{c}\text { Sig. } \\
\text { (2- tailed) }\end{array}$ \\
\hline Daily products & 2.66 & 3.53 & 0.98 & -8.08 & .000 \\
\hline School signs & 2.48 & 3.41 & 0.90 & -9.63 & .000 \\
\hline Street signs & 2.70 & 3.67 & 1.00 & -8.76 & .000 \\
\hline Store signs & 2.64 & 3.61 & 1.00 & -8.82 & .000 \\
\hline Store items & 2.44 & 3.47 & 0.95 & -9.65 & .000 \\
\hline Restaurants & 3.16 & 3.74 & 0.96 & -5.58 & .000 \\
\hline Translation & 2.80 & 3.11 & 1.10 & -2.60 & .010 \\
\hline
\end{tabular}

Note. $N=88$.

$p<.05$.

\section{Students' Self-Perceived Language Ability After the Activity}

In response to the self-rated items on language gain in vocabulary, translation skills, and overall language ability, many students strongly agreed that the English Detective Activity could increase their vocabulary size. They also believed that the activity improved their general English ability and translation skills (see Table 2).

\section{Table 2}

Results of the Paired Sample t-test on Students' Self-Rated Skills Pre- and Post-Activity

\begin{tabular}{|l|c|c|c|c|c|}
\hline & $\begin{array}{c}\text { Means } \\
\text { Pre-test }\end{array}$ & $\begin{array}{c}\text { Means } \\
\text { Post-test }\end{array}$ & Std. Dev. & $T$ & $\begin{array}{c}\text { Sig. } \\
\text { (2- tailed) }\end{array}$ \\
\hline Vocabulary & 3.47 & 3.67 & 0.71 & -2.69 & 0.01 \\
\hline General ability & 3.45 & 3.63 & 0.73 & -5.00 & 0.01 \\
\hline Translation & 3.26 & 3.47 & 0.71 & -2.60 & 0.03 \\
\hline
\end{tabular}

Note. $N=88$.

$p<.05$.

As for whether school courses included practical English usage, the mean was not as high (see Table 3). According to the survey results, students thought that teachers should teach more practical English usage in class. While teachers may be required to adhere to a class syllabus and materials that are both limited and rigid, they could find ways to incorporate more authentic materials into their classroom teaching and create a learning environment that cultivates autonomous learning. 
Table 3

Results of the Paired Sample t-test on Students' Opinions Pre- and Post-Activity

\begin{tabular}{|l|c|c|c|c|c|}
\hline & $\begin{array}{c}\text { Means } \\
\text { Pre-test }\end{array}$ & $\begin{array}{c}\text { Means } \\
\text { Post-test }\end{array}$ & Std. Dev. & $T$ & $\begin{array}{c}\text { Sig. } \\
\text { (2- tailed) }\end{array}$ \\
\hline $\begin{array}{l}\text { Practical usage } \\
\text { included in } \\
\text { instruction }\end{array}$ & 3.30 & 3.41 & 0.80 & -1.30 & 0.19 \\
\hline $\begin{array}{l}\text { Need for } \\
\text { incorporating } \\
\text { practical English } \\
\text { usage }\end{array}$ & 4.07 & 4.05 & 0.54 & 0.39 & 0.67 \\
\hline
\end{tabular}

Note. $N=88$.

$p<.05$.

\section{Difficulties for the Activity}

Although this study exhibited positive results, some problems emerged. The purpose of the activity is to increase students' awareness of and contact with English; it is not meant to encourage competition. The author first assigned the activity as a co-curricular activity for extra credit. Although provided with incentives such as extra credit and prizes, students showed very little motivation to do the activity because it was not part of the formal curriculum. As a result, the activity was changed to a course requirement. Constant reminders and a collection of drafts midway through the project were necessary to assure that students remained on task. Moreover, with this activity, it is possible that some students might attempt to benefit from the effort of others without taking their own notes and it might be difficult for teachers to verify the authenticity of students' data. As in the completed study, indications are that most students will be honest and do their own work. Teachers could show or post students' findings to honor their work so that students feel their effort is worthwhile. Students' commitment to outside classroom work varies (Gibbs, 1999; Pearson, 2004), but those with a low level of commitment should not deter teachers from creating learning tasks outside of class. For students who are more teacher-dependent and are used to being spoon-fed information, more encouragement and impetus may be necessary for them to embark on a language quest.

\section{Conclusion}

The out-of-class activity is intended to help students realize that although they are not in an English-speaking environment, they are still surrounded by English. The present study demonstrates that this activity encourages students to expand their language experience to outside the classroom by making them aware of existing and available English language opportunities in their surroundings. Instead of presenting only formulaic English in textbooks, an out-of-class activity can increase students' exposure to English in existing and familiar contexts. In addition to providing authentic language exposure, the English Detective Activity can draw students into a discussion of the appropriateness of language usage and translation. Their conscious attention to English usage in the real world can also increase students' language ability and, in particular, improve their vocabulary.

This study shows the potential value of incorporating out-of-class activities for enriched learning outside of school and for autonomous learning. Non-English speaking countries such as China, Japan, and Vietnam are witnessing an increasing need for international communication and collaboration and have recognized the impact of English as a universal 
be more incorporation of English in the environment. However, it cannot be assumed that students will automatically absorb the English displayed in their environment. Institutions need to "[transcend] the artificial boundaries of in-class and out-of-class learning experiences" and provide ample opportunities for learning outside of classrooms (Kuh, Douglas, Lund, \& RaminGyurnek, 1994). Thus, it is worthwhile for educators in similar EFL environments to implement this purposeful out-of-class activity as a means of promoting English language awareness and enhancing the learning of English in their local contexts.

\section{Author Note}

Siao-cing Guo, Department of Applied Foreign Languages, National Taipei College of Business.

Correspondence concerning this article should be addressed to Siao-cing Guo, Department of Applied Foreign Languages, National Taipei College of Business, No. 321, Sec. 1, Jinan Road, Zhongzheng District, Taipei City 100, Taiwan (R. O. C.). E-mail: ching.chu@gmail.com 


\section{References}

Bas, G. (2008). Implementation of multiple intelligences supported project-based learning in EFL/ESL classrooms. Retrieved from http://www3.telus.net/linguisticsissues/mi

Dam, L. (1995). Learner autonomy: From theory to classroom practice. Dublin, Ireland: Authentik.

Davies, A. (2006). What do learners really want from their EFL courses? ELT Journal, 60(1), 312. http://dx.doi.org/10.1093/elt/cci076

Educational Testing Service (ETS). (2010). TOEFL test and score data summaries. Retrieved from http://www.ets.org/toefl/research/test_score_data_summary/

Field, J. (2007). Looking outwards, not inwards. ELT Journal, 61(1), 30-38. http://dx.doi.org/10.1093/elt/ccl042

Foss, P., Carney, N., McDonald, K., \& Rooks, M. (2007). Project based learning activities for short-term intensive English programs. Asian EFL Journal, 23. Retrieved from http://www.asian-efl-journal.com/pta_Oct_07_ypf\&nc\&km\&mr.php

Fried-Booth, D. L. (2001). Project work. Oxford, England: Oxford University Press.

Gibbs, G. (1999). Changing student learning behavior outside of class. Essays on teaching excellence. Retrieved from http://teaching.uchicago.edu/ete/99-00/Gibbs.htm

Griffiths, G., \& Keohane, K. (2000). Personalizing language learning. Cambridge, England: Cambridge University Press.

Guo, S. C. (2011, September). Examining the relationship between outside reading, reading habits, and reading speed. Paper presented at the First Extensive Reading World Congress, Kyoto, Japan.

Hillyard, L., Reppen, R., \& Vasquez, C. (2007). Bringing the outside world into an intensive English program. ELT Journal, 61(2), 126-143. http://dx.doi.org/10.1093/elt/ccm005

Hsieh, S. M., \& Chu, S. C. (2006). Making "friends" an English learning partner. In Y.-N. Leung, M. Jenks, \& C. S. Hsia (Eds.), New aspects of English language teaching and learning (pp. 351-361). Taipei, Taiwan: Crane.

Hui, Y. (2010). Teacher-learner autonomy in second language acquisition. Canadian Social Science, 6(1), 66-69.

Hyland, F. (2004). Learning autonomously: contextualizing out-of-class English language learning. Language Awareness, 13(3), 180-202. http://dx.doi.org/10.1080/09658410408667094

Kuh, G., Douglas, K., Lund, J., \& Ramin-Gyurnek, J. (1994). Student learning outside the classroom: Transcending artificial boundaries (ASHE-ERIC Higher Education Report No. 8 [ED39444]). Washington, DC: Graduate School of Education and Human Development, George Washington University

Kuo, I. (2006). Addressing the issue of teaching English as lingua franca. ELT Journal, 60(3), 213-221. http://dx.doi.org/10.1093/elt/ccl001

Little, D. (2007). Language learner autonomy: Some fundamental considerations revisited. Innovation in Language Learning and Teaching, 1(1), 14-29. http://dx.doi.org/10.2167/illt040.0

Little, D. (2009). Language learner autonomy and the European Language Portfolio: Two L2 English examples. Language Teaching, 42(2), 222-233. http://dx.doi.org/10.1017/S0261444808005636

Mathews-Aydinli, J. (2007, April). Problem-based learning and adult English language learners. CAELA Brief, 1 - 7. Available at http://www.cal.org/caela/esl_resources/briefs/Problembased.pdf

Ministry of Education. (2010). An education overview. Retrieved from http://english.moe.gov.tw/ct.asp?xltem $=4133 \&$ CtNode $=2003 \& \mathrm{mp}=2$

Nunan, D. (1989). Understanding language classrooms. New York, NY: Prentice Hall. 
Pearson, N. (2004). The idiosyncrasies of out-of-class language learning: A study of mainland Chinese students studying English at tertiary level in New Zealand. Proceedings of the Independent Learning Conference, 2003. Available from www.independentlearning.org/ila03/ila03_pearson.pdf

Reinders, H. (2010). Towards a classroom pedagogy for learner autonomy: A framework of independent language learning skills. Australian Journal of Teacher Education, 35(5), 40-55.

Resnick, L. (1987). The 1987 presidential address: Learning in school and out. Educational Researcher, 16(9), 13-20. http://dx.doi.org/10.2307/1175725

Thanasoulas, D. (2000). What is learner autonomy and how can it be fostered? The Internet Journal, 6(11). Retrieved from http://iteslj.org/Articles/Thanasoulas-Autonomy.html

Ton, H., \& Pham, H. H. (2010). Vietnamese teachers' and students' perceptions of global English. Language Education in Asia, 1, 48-61. http://dx.doi.org/10.5746/LEiA/10/V1/A05/Ton_Pham

Torikai, K. (2005). The challenge of language and communication in twenty-first century Japan. Japanese Studies, 25(3), 249-256. http://dx.doi.org/10.1080/10371390500342733

Xiao, L., \& Luo, M. (2009). English co-curricular activities: A gateway to developing autonomous learners. CamTESOL Selected Papers, 5, 239-251. http://www.camtesol.org/Download/Earlier_Publications/Selected_Papers_Vol.5_2009. pdf

Yoshikawa, H. (2005). Recognition of world Englishes: Changes in Chukyo University students' attitudes. World Englishes, 24(3), 351-360. http://dx.doi.org/10.1111/j.00832919.2005.00416.x 


\section{Appendix}

Students' Language Data Samples

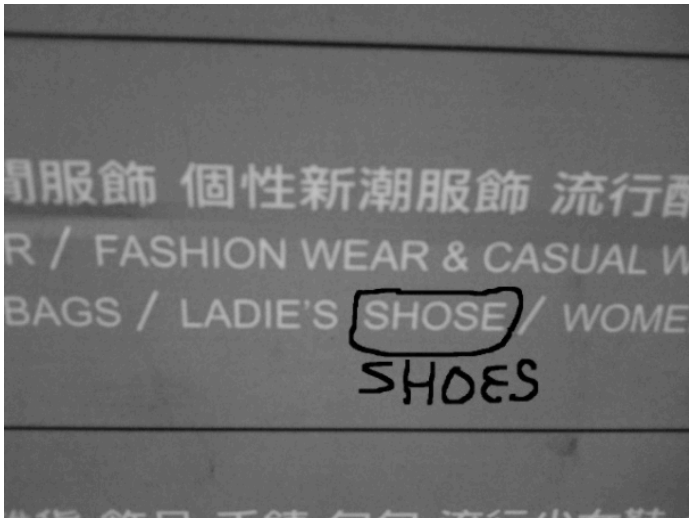

LADIE'S SHOSE $\rightarrow$ LADIES' SHOES

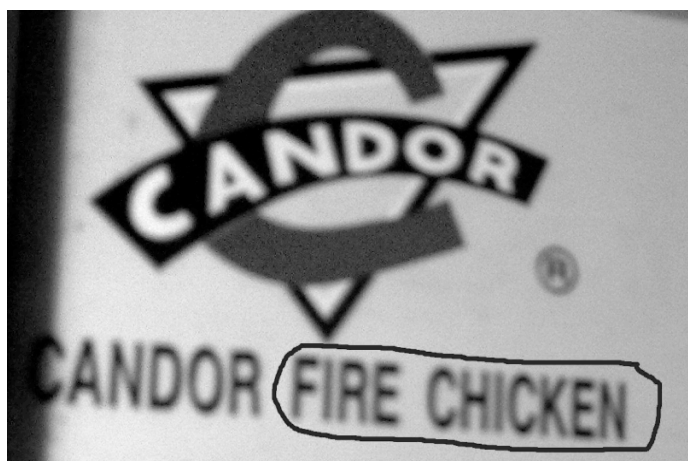

FIRE CHICKEN $\rightarrow$ FRIED CHICKEN

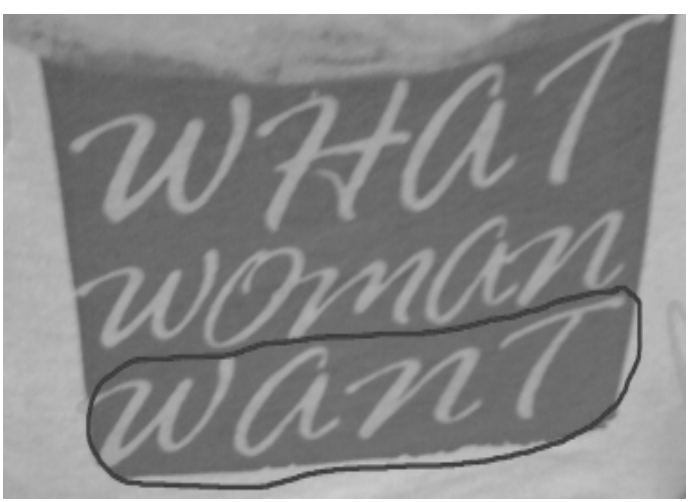

What woman want $\rightarrow$ What women want

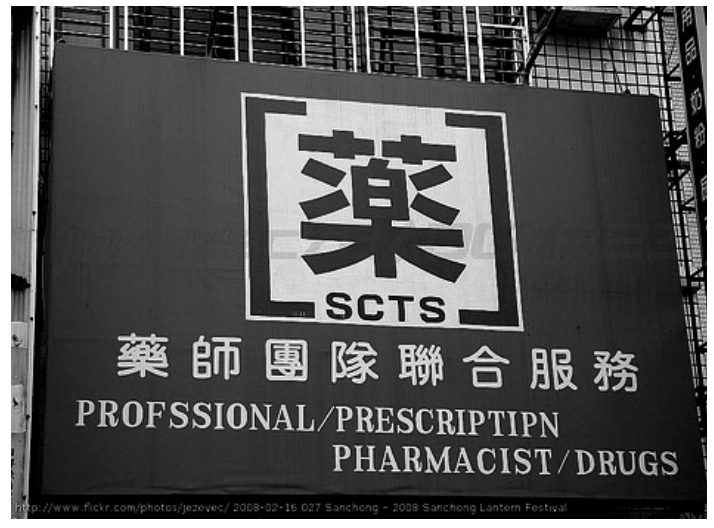

PROFSSIONAL $\rightarrow$ PROFESSIONAL PRESCRIPTIPN $\rightarrow$ PRESCRIPTION

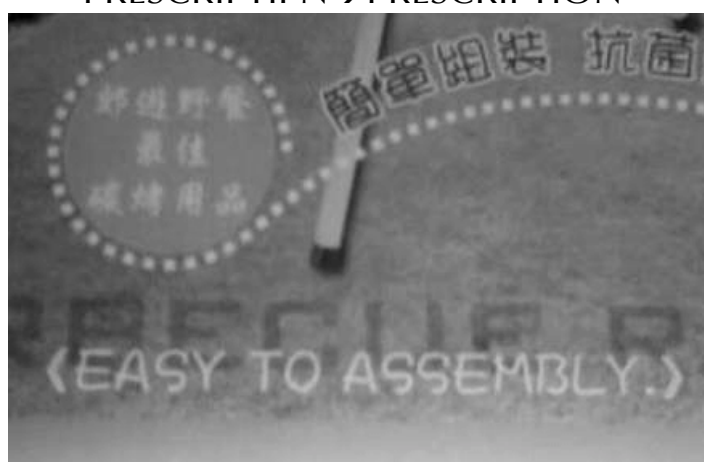

EASY TO ASSEMBLY $\rightarrow$ EASY TO ASSEMBLE
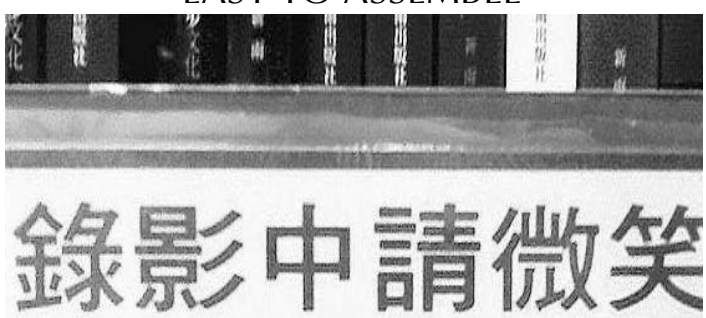

Record image to win to ask to smile 録画する中で倣笑んでください

Record image to win to ask to smile $\rightarrow$ Smile, you are on camera 